\title{
Effect of Inorganic Fertilization on the Zooplankton Production in Fresh Water Pond
}

\author{
Yakubu, A. F.; Adams T. E.; Olaji E. D.; Adebote. E.E and Okabe, O.R.
}

Department of Aquaculture Nigerian Institute for oceanography and Marine Research P.M.B 4015 Sapele Outstation Delta State Nigeria.

\begin{abstract}
Zooplankton production in newly constructed fish pond fertilized with Nitrogen, Phosphorus and Potassium (N: P: K) and urea fertilizer were compared with unfertilized ponds. Zooplankton production was significantly more $(P \leq 0.05)$ in fertilized system than in the unfertilized systems. The Zooplankton fauna was generally dominated by rotifers and copepods. Also the fertilization had no significant effect $(P \leq 0.05)$ on the water chemistry. Keywords — Inorganic Fertilization, Water Pond.
\end{abstract}

\section{INTRODUCTION}

Fertilization is as important for fish cultivation as it is in agriculture because of the increasing mineralization of the pond system, which provides adequate nutrients for plankton growth. The photosynthesizing micro-organisms of the plankton are referred to as the phytoplankton while the non photo-synthesizing component is the zooplankton. Zooplankton form the most valuable food resource in any aquatic system for fish production. It is produced at almost no cost, replaces costly supplementary feed and it is rich in protein and vitamins (Hepher and Pruginin, 1981). It is worthwhile, therefore to increase the production of this natural food (zooplankton) in the pond as such as possible to allow for an increase in total yield. This can be achieved with the use of fertilizers (inorganic or organic). However care has to be taken with the application i.e. strictly according to the standard dosage so as not to foul up the system.

The study is aimed at investigating the effect of inorganic fertilizers on zooplankton production in fresh water ponds.

\section{MATERIALS AND METHODS}

Pond fertilization: Six 0.2 ha newly ponds of Nigerian Institute for Oceanography and Marine Research out station at Sapele Delta State Nigeria were used for the experiment. Three of the ponds (A, B and C ) were fertilized initially with N:P:K (15:15:15) at a rate of $125 \mathrm{~kg} / \mathrm{ha}$ and followed a week later with urea fertilizer $250 \mathrm{~kg} / \mathrm{ha}$ (Charkroff, 1976).while pond ( D, E and F ) were not fertilized which serves as control.

Zooplankton Sampling: Zooplankton sampling commenced two weeks after the first fertilization. Plankton samples were collected daily for two weeks with fine meshed nets of $154 \mathrm{ym}$. Twenty millimeters (20ml) of the concentrate volume was then preserved by adding few drops of $4 \%$ formalin. Three drops of lugol solution was then added to the plankton sample and left for twenty four hours. After which the sample was reduced to ten millimeters $(10 \mathrm{ml})$ by decanting. The supernatant aliquot (Adeyemo, 1991).

The physico-chemical parameters (temperature, turbidity, hydrogen ion concentration, and dissolved oxygen nitrate concentration and phosphate concentration of the sampled ponds were also taken (Table 1)

Zooplankton Analysis: The $1 \mathrm{ml}$ Sedgwick-rafter counting chamber was filled with the concentrate sample, covered with a cover slip and examined under a calibrated microscope at low power. For rotifers, zooplankter observed was counted, and recorded. Counting was done five times per sample to ensure that all the plankton were counted. For the crustaceans (Cladocera and copepod), micropipette was used in transferring them into glycerol on a clean glass slide. Fine tungsten needle was used to dissect cut parts that are of taxonomic importance. The dissected crustacean was later examined under a calibrated compound microscope and recorded.

Identifications and Estimation of Abundance: Identifications of the zooplankton species were made by reference to Green (1960, 1962); Imevbore (1965): Egborge (1972, 1981); Pontin (1978); Jeje and Fernandi (1986); and Adeyemo (1991). The average abundance of each species of zooplankton was estimated using the formula;

$$
\text { : A } \underline{\mathrm{YZ}}
$$

A. $=$ Average number of zooplankton species per liter 
$\mathrm{Y} . \quad=\quad$ Average number of zooplankton

species per sample

$\begin{array}{lll}\mathrm{Z} . & = & \text { Concentrate volume }(\mathrm{ml}) \\ \mathrm{a} . & = & \text { Original volume (liter) } \\ \mathrm{x} . & = & \text { Volume of counting chamber } \\ (\mathrm{ml}) . & \end{array}$

\section{RESULTS}

Checklist of the zooplankton. Fourteen zooplankton species were identified. These consist of one species of Cladocera, three species of Copedpda and ten species of Rotifera. The checklist of the species is as follows:

$\begin{array}{ll}\text { Phylum } & \text { Arthopoda } \\ \text { Class } & \text { Crustancea } \\ \text { Subclass } & \text { Branchiopodia } \\ \text { Family } & \text { Daphnidae }\end{array}$

Dsphnialongispina Muller

Order Copepoda.

Family Cyclcpoida

MicrocyclopsrubellusLilljeberg

MicrocycolopsvaricansSars

Thermocyclopscrassus Fischer

$\begin{array}{ll}\text { Phylum } & \text { Rotifera } \\ \text { Class } & \text { Monogononta } \\ \text { Family } & \text { Asplanchnidae }\end{array}$

Asplanchns priodonta G00se

Family

Branchionidae
Branchionusangularis Goose

Branchionuscalycifiorouscalyciflorousfall

as

(Rousselet)

Branchionusleydigirotundus

Branchionusurceolatrisbennini

(Leissling)

Zacharias

\section{Branchionusfalcatusfalcatus}

Notholcasquamula

(muller)

Family

Lecanidae

lunaris Ehrenberg

Lecane (Monostyla)

Lecane (monostyia)

bulla Gosse

Lecaneluna Muller

Table.1: Estimated Mean Abundance of Zooplankton Species in the Sampled Ponds.

Fertilized Ponds

Unfertilized Ponds

\begin{tabular}{|c|c|c|c|c|c|c|c|}
\hline $\mathrm{S} / \mathrm{NO}$ & Species & $\begin{array}{l}\text { Pond A } \\
\text { (org/I) }\end{array}$ & $\begin{array}{l}\text { Pond B } \\
\text { (org/I) }\end{array}$ & $\begin{array}{l}\text { Pond C } \\
\text { (org/I) }\end{array}$ & $\begin{array}{l}\text { Pond D } \\
\text { (org/I) }\end{array}$ & $\begin{array}{l}\text { Pond E } \\
\text { (org/I) }\end{array}$ & $\begin{array}{ll}\begin{array}{l}\text { Pond } \\
(\mathrm{org} / \mathrm{I})\end{array} & \text { F }\end{array}$ \\
\hline 1. & Daphnia longispina & $100 \pm 20$ & $1,100 \pm 100$ & $600 \pm 435.9$ & $200 \pm 173.2$ & & \\
\hline 2. & $\underline{\text { microcyclops ribellus }}$ & $400 \pm 70$ & $800 \pm 264.5$ & & & & \\
\hline 3. & Microcyclops varicans & & $300 \pm 264.5$ & $900 \pm 360.5$ & & $100 \pm 34.6$ & \\
\hline 4. & Thereocyclops crasuss & & & $200 \pm 100$ & & $100 \pm 34.6$ & \\
\hline 5. & Asplanchua priodosta & $600 \pm 1802.7$ & $5,000 \pm 178.2$ & $1,000 \pm 264.6$ & $300 \pm 173.2$ & $400 \pm 200$ & $100 \pm 34.6$ \\
\hline 6 & Branchionus angularis & $7,000 \pm 1732.1$ & $8,000 \pm 1732.1$ & $3,000 \pm 26496$ & $1,000 \pm 400$ & & \\
\hline 7. & Branchonus scalyciflorusca & $4,000 \pm 2645.7$ & & & & $680 \pm 173.2$ & \\
\hline 8. & B. Leydigi rotundus & & $1,400 \pm 400$ & $1,600 \pm 360.6$ & & & $200 \pm 173.2$ \\
\hline 9. & B. Urceolaris beanini & $1,800 \pm 1216.5$ & & $1,000 \pm 264.6$ & & & \\
\hline 10. & B. Falcatus falcatus & $1,800 \pm 200$ & $5,000 \pm 1,000$ & $3,000 \pm 264.6$ & $400 \pm 264.6$ & & $100 \pm 34.6$ \\
\hline 11. & Notholca squamulas & $800 \pm 173.2$ & & & & & \\
\hline 12. & Lecane(Nonontyla lunaris & & & $400 \pm 200$ & & & \\
\hline 13. & Lecane (Nonostyla) balla & $700 \pm 435.8$ & & & & & \\
\hline 14. & Lecane luna & $1,300 \pm 416.3$ & $100 \pm 264.6$ & & $200 \pm 100$ & $200 \pm 100$ & $300 \pm 100$ \\
\hline
\end{tabular}

$\mathrm{P} \leq 0.05$.

Abundance. The data on mean zooplankton abundance is presented in Table 1. The abundance ranged from 100 org/liter to 8,000 org/liter. Rotifers were more abundant than Copepods and the Cladocera. Zooplankton was more abundant in fertilized ponds (A, B and C) than the unfertilized ponds (D, E and F). Zooplankton abundance was significantly more $(\mathrm{P} \leq 0.05)$ in the fertilized ponds than in the unfertilized ponds. 
Species Occurrence. Table 2. Shows the occurrence of zooplankton species in the sampled ponds. The number of species per pond varied from four to ten and these values respectively corresponds to about $28.6 \%$ and $71.4 \%$ of the total number of recorded species. The highest, was recorded from a fertilized pond (Pond IA) while the least (four) occurred in an unfertilized pond (Pond F)

Table.2: The Occurrence of zooplankton Species in the Sampled Ponds.

\begin{tabular}{|l|l|l|l|l|c|c|c|c|}
\hline S/NO. & Species & $\begin{array}{l}\text { POND } \\
\mathrm{A}\end{array}$ & $\begin{array}{l}\text { POND } \\
\mathrm{B}\end{array}$ & $\begin{array}{l}\text { POND } \\
\mathrm{C}\end{array}$ & $\begin{array}{l}\text { POND } \\
\mathrm{D}\end{array}$ & $\begin{array}{l}\text { POND } \\
\mathrm{E}\end{array}$ & $\begin{array}{l}\text { POND } \\
\mathrm{F}\end{array}$ & $\begin{array}{l}\text { Frequency of } \\
\text { Occurrence of } \\
\text { Species }\end{array}$ \\
\hline 1. & Daphnia longispna & $\mathrm{X}$ & $\mathrm{X}$ & $\mathrm{X}$ & $\mathrm{X}$ & & & $66.7 \%$ \\
\hline 2. & Microcycl0psrubellus & $\mathrm{X}$ & $\mathrm{X}$ & & & & & $33.3 \%$ \\
\hline 3. & Microcyclios varicans & & $\mathrm{X}$ & $\mathrm{X}$ & & $\mathrm{X}$ & & $50.0 \%$ \\
\hline 4. & Theraocyclops crassuss & & & $\mathrm{X}$ & & $\mathrm{X}$ & & $33.3 \%$ \\
\hline 5. & Asplanchnap riodonta & $\mathrm{X}$ & $\mathrm{X}$ & $\mathrm{X}$ & $\mathrm{X}$ & $\mathrm{X}$ & $\mathrm{X}$ & $100 \%$ \\
\hline 6. & Branchionus angularis & $\mathrm{X}$ & $\mathrm{X}$ & $\mathrm{X}$ & $\mathrm{X}$ & $\mathrm{X}$ & & $66.7 \%$ \\
\hline 7. & Branchionus Calyciflorous & $\mathrm{X}$ & & & & $\mathrm{X}$ & & $33.3 \%$ \\
\hline 8. & B. Leydigi rotundus & & $\mathrm{X}$ & $\mathrm{X}$ & & & $\mathrm{X}$ & $50 \%$ \\
\hline 9. & B. urceolaris beaniti & $\mathrm{X}$ & & $\mathrm{X}$ & & & & $33.3 \%$ \\
\hline 10. & B. falcatus falcatus & $\mathrm{X}$ & $\mathrm{X}$ & $\mathrm{X}$ & $\mathrm{X}$ & & $\mathrm{X}$ & $83.3 \%$ \\
\hline 11. & Notholens quajula & $\mathrm{X}$ & & & & & & $16.7 \%$ \\
\hline 12. & Lecane (Nonostyla) lunaris & & & $\mathrm{X}$ & & & & $16.7 \%$ \\
\hline 13 & Lecane (Nonostyla) balla & $\mathrm{X}$ & & & & & & $16.7 \%$ \\
\hline 14. & Lecane luna & $\mathrm{X}$ & $\mathrm{X}$ & & $\mathrm{X}$ & $\mathrm{X}$ & $\mathrm{X}$ & $83.3 \%$ \\
\hline & $\begin{array}{l}\text { Frequency of occurrence of } \\
\text { zooplankton per pond }\end{array}$ & $71.4 \%$ & & $54.3 \%$ & $35.7 \%$ & $35.7 \%$ & & \\
& & & $57.1 \%$ & & & & $28.6 \%$ & \\
\hline
\end{tabular}

Water Chemistry: Table 3 shows the physic-chemical characteristics of the ponds. However, the parameters were not significantly different $(\mathrm{P} \leq 0.05)$ as a result of the application of fertilizers.

Table.3: Mean Values of the sampled physic-chemical parameters.

\begin{tabular}{|l|l|c|l|l|l|}
\hline Pond & $\begin{array}{l}\text { Water } \\
\text { temperature 0C }\end{array}$ & $\mathrm{pH}$ & $\begin{array}{l}\text { Dissolved oxygen } \\
(\mathrm{mg} / \mathrm{L})\end{array}$ & $\mathrm{N} 03 \mathrm{mg} / \mathrm{L}$ & $\mathrm{P} 04 \mathrm{mg} / \mathrm{L}$ \\
\hline $\mathrm{A}$ & $31.0 \pm 0.82$ & $6.5 \pm 0.25$ & $9.45 \pm 0.47$ & $0.04 \pm 0.03$ & $0.14 \pm 0.11$ \\
\hline $\mathrm{B}$ & $31.0 \pm 1.41$ & $65 \pm 0.45$ & $10.8 \pm 0.47$ & $0.02 \pm 0.02$ & $0.13 \pm 0.01$ \\
\hline $\mathrm{C}$ & $30.0 \pm 2.10$ & $6.7 \pm 0.50$ & $7.05 \pm 0.01$ & $0.02 \pm 0.01$ & $0.11 \pm 0.09$ \\
\hline $\mathrm{D}$ & $31.0 \pm 0.82$ & $6.1 \pm 0.08$ & $6.2 \pm 0.23$ & $0.002 \pm 0.003$ & $0.09 \pm 0.12$ \\
\hline E & $31.5 \pm 1.41$ & $5.8 \pm 0.50$ & $6.1 \pm 0.03$ & $0.003 \pm 0.002$ & $0.10 \pm 0.09$ \\
\hline F & $29.7 \pm 0.21$ & $6.0 \pm .42$ & $6.5 \pm 0.25$ & $0.004 \pm 0.002$ & $0.10 \pm 0.16$ \\
\hline
\end{tabular}

\section{DISCUSSION}

The use of fertilization in fish ponds is not new. It has been used for centuries to provide basic nutrient components needed for rapid development of plankton. The increase in primary productivity following fertilization usually results in greater zooplankton abundance (Boyd, 1982). This is evident in the zooplankton population that was significantly more $(\mathrm{P} \leq 0.05)$ in the fertilized system than the unfertilized system in the study. The same finding was also reported by McIntire and Bond (1962) using inorganic fertilizer and Dendy et al (1968) recorded maximum density of zooplankters in fertilized ponds of Alabama. Similar 
observations include that of Hall et al. (1970) with high turnover ratio of zooplankton in fertilized ponds than the unfertilized and Sharma et al. (1990) with a record of significant zooplankton production $(\mathrm{P} \leq 0.05)$ after fertilization with inorganic fertilizer.

The observed zooplankton fauna was dominated by the rotifers followed by the copepods and with only one species of Cladocera. This confirms the findings of Jeje and Fernando (1986) that rotifers and copepods are the most widely distributed of all the zooplankton and O'Brien and De Moyeis 1974, cited by Sharma et. al. (1990) found that mineral fertilizers (N:P:K and Urea have inhibiting effects on the plank tonic Cladocera. Also from the observed physic-chemical parameters. Its evident that there was no significant difference $(\mathrm{P} \leq 0.05)$ between the fertilized and unfertilized system. Although, there was a slight increase in the $\mathrm{pH}$ of the fertilized system, an increase like this was observed by Lewkowicz and Lewkowicz (1976) and Sharma et.al (Op.cit.) using inorganic fertilizer generally inorganic fertilizer increases $\mathrm{pH}$ (Sharma et.al. 1987). Again, no significant influence was seen in the orthophosphate and nitrate concentration of the pond as a result of the application of the fertilizers. Similar result were observed by Wrobel (1962), Sharma et al. (1990) and Delince (1992). The insignificant influence of the fertilizers on the orthophosphate concentration in the pond after fertilization has been attributed to the sorption of the excess into the sediment (Marsden, 1989). Also short lived peaks of ammonium and nitrate in the pond following fertilization results in the insignificant effects of the fertilizers on the nitrate concentration (Bouldin et. al: 1974).

In conclusion, it can be inferred that N.P.K. and Urea fertilizer when applied strictly according to the standard dosage increases production of zooplankton without a significant effect on the water chemistry.

\section{REFERENCES}

[1] Adeyemo. A.A. (1991): The Taxa composition abundance and distribution pattern of zooplankton fauna of rivers and streams in Central Nigeria M.Sc. Thes is, ObafemiAwolowo University Ile-Ife, 156pp.

[2] Bouldin, D.E., Honson, R.J, Burda, C. and Kao, C.W. (1974): Losses of inorganic nitrogen from aquatic systems J. envirQual 3: 107 -114.

[3] Boyd, C.E. (1982): Water quality Management for pond fish culture Elsevier Scientific publication company, Amsterdam, 318pp.

[4] Charkroff, M (1976): Freshwater fish Pond Culture and Management, V.I.T.A. 196pp
[5] Delince, G. (1992): Ecology of the fish pond ecosystems with special reference to Africa Kluwer Academic Publishers, London 230pp

[6] Dendy, J.S., Varikul, V., Sumawidjaja, K., Potaros, M. (1968): Production of Tilapia Mossambica Peters, plankton and benthos as parametres for evaluation of nitrogen in pond fertilizers. Proc. World Symposium on Warm- water Pond fish Culture, F.A.O. United Nation, Fish Rep. 44: 226-240.

[7] Egborge, A.B.M.(1972): A preliminary checklist of the zooplanktonic organisms of The River Osun, in the Western State of Nigeria, Nig.S. Sci. 6(1): 67-71.

[8] Egborge, A.B.M. (1981): The composition, seasonal variation and distribution of Zooplankton in Lake Asejire, Nigeria. La Revue de zoologieAfricaine. Vol.95 FASC (1-1981): 137 - 180.

[9] Green, J, (1960): Zooplankton of the River Sokoto. The Rotifera. Proc. Zool. Soc. London 135: 491 523.

[10] Green, J, (1962): Zooplankton of the River Sokoto. The Crustacea Proc. Zool. Soc. London 151: 343-378.

[11] Hall, D.J., Cooper, W.E., and Werner, E.C. (1970): an experimental approach to the Production dynamics and structure of freshwater animal communities. LimnolOceanogr; 7: 131 -1354.

[12] Hepher, B. and Pruginin,Y.(1981): Commercial Fish Farming, John Wiley and Sons New Your 261pp.

[13] Imevbore, A.M.A. (1965). A preliminary checklist of the planktonic organisms in Eleiyele Reservoir, Ibadan Niger. >W. Afri. Ass. 10: 5660.

[14] Jeje, C. Y. and Fernando, C.H. (1986): A practical guide to the identification of Nigerian zooplankton. Kainji lake Research Institute, Kainji, 141pp.

[15] Lewkowicz, M. and Lewkowicz, S (1976): Organic and Inorganic nutrient enrichment and the living conditions of the carp fry in first roaring ponds. Physic0-chemical factors and the zooplankton. Actahydrobicl. 18(3):235-357

[16] Marsden, M.W. (1989): Lake restoration by reducing external phosphorus loading: The influence of sediment release. Fresh wat. Biol. 21: 129 -162.

[17] McIntire, C.D. and Bond, C.E. (1962): Effects of Artificial fertilization on plankton And benthos abundance in four experimental ponds. Trans. Amer. Fish. Soc. 91: 303 - 312.

[18] Pontin, R.M (1978): A key to the freshwater planktonic and semi planktonic Rotifera of the British 
Isles. Fresh water Biological Association Scientific

Publication, NO. 38.

[19] Sharma, O.P., Rajbanshi, V.K., Sharma, L.L. (1987):

Water quality and zooplankton Production in waters

fertilized on the basis of P.N. ratios. J. Hydrobiology 3(5): $25-28$.

[20] Sharma, O.P., Rajbanshi, V.K., and Sharma, L.L., (9190): NPK fertilization: Production of fish food organisms in relation to water characteristics. In Proceedings of the Second Asian Fisheries Forum Tokyo, Japan 185-188.

[21] Wrobel, S. (1962): The effects of nitrogenous phosphate fertilization on the Chemical composition of water primary production of phytoplankton and fish Yield in ponds Actahydrobiol 4(2): 151 - 204. 